\title{
Prognostic Significance of p21 and p53 Expression in Gastric Cancer
}

\author{
Young-Ho Seo, M.D., Young-Eun Joo, M.D., Sung-Kyu Choi, M.D., \\ Jong-Sun Rew, M.D., Chang-Soo Park, M.D." and Sei-Jong Kim, M.D. \\ Departments of Internal Medicine and Pathology*. \\ Chonnam National University Medical School, Gwangju, Korea
}

Background: Cyclin-dependent kinase inhibitors (CDKI), including p21, p27 and p57 of the KIP family, are negative regulators of cell cycle progression and potentially act as tumor suppressors. The expression of p21 is induced by tumor suppressor gene p53. Mutations of p53 are common and found in various human cancers. Thus, the function of p21 as a tumor suppressor may be not retained after p53 mutation in human cancers. The aim of our study was to evaluate the tumor suppressive activity of p21 and p53 in human gastric cancer.

Methods: One hundred and two patients who underwent surgery for gastric cancer at Chonnam National University Hospital were selected retrospectively for this study. The primary selection criteria were the availability of formalin-fixed and paraffin-embedded blocks and sufficient clinical follow-up for tumor-specific survival analysis. In this study, we examined the expression of p21 and p53 in human gastric cancer tissue by immunohistochemistry and the correlation between their expression and clinicopathological variables.

Results: p21 and p53 immunoreactivities were localized in the nuclei of carcinoma cells. Positive nuclear expression of p21 and p53 was demonstrated in 63.7 and $33.3 \%$ of cancer tissues, respectively. No apparent correlation was noted between p21 and p53 expression. Negative expression of p21 correlated with advanced stage and lymph node metastasis $(p=0.028$ and 0.017 , respectively). Moreover, negative expression of p21 correlated with poor survival $(\rho=0.037)$. Positive expression of $\mathrm{p} 53$ correlated with depth of tumor invasion $(p=0.029)$. However, no significant correlation could be observed between the status of $p 53$ expression and survival. Combined analysis of p21 and p53 status showed that p21 negative and p53 positive tumors had a poorer survival than other group tumors $(p=0.026)$.

Conclusion: These results suggest that the status of p21 and p53 expression may help in predicting the aggressive behavior of gastric cancer. However, further studies are warranted to clarify the impact of p53 on the function of p21 as a tumor suppressor.

Key Words : Oncogene protein p21 (ras), Protein p53, Immunohistochemistry, Stomach Neoplasms

\section{INTRODUCTION}

Cyclin-dependent kinases (CDKs) regulate the progression of the cell cycle". The CDKs phophorylate the retinoblastoma susceptibility gene protein which then allows the progression of the cell cycle from $\mathrm{G} 1$ into the S-phase ${ }^{1-3)}$. The CDKs are activated by phosphorylation by activating CDK-activating kinases. The CDKs inhibitors block this activation of CDKs by CDK-activating kinases. The inhibition of CDK activation results in the inhibition of retinoblastoma susceptibility gene phosphorylation and, consequently, in cell cycle arrest in the G1 phase ${ }^{1-3)}$. Therefore, the CDK inhibitors have been regarded as putative tumor suppressors. The CDK inhibitors can be considered as two distinct groups of enzymes. Group 1 is Cip/Kip family, including p21, p27 and $p 57^{4-81}$. Group 2 is INK family including $p 15, p 16, p 18$ and $p 19^{9-12)}$. Among the 
many reported CDK inhibitors, decreased expression of p21 and p27 has been described in neoplastic cells and has also been associated with tumor progression and poor outcome in various human cancers, including gastric cancer ${ }^{13-20 !}$.

The p53 tumor suppressor gene is believed to play a pivotal role in preventing the uncontrolled cellular growth characteristic of cancer. p53 is mutated or deleted in about $50 \%$ of spontaneously arising tumors and this alteration of p53 is strongly associated with tumor progression and metastasis $^{21-24}$. Recently, it has been reported that the expression of $\mathrm{p} 21$ is induced by the tumor suppressor gene $p 53^{4,7,25,26 l}$. Thus, the function of p21 as a tumor suppressor may be not retained after p53 alteration in human cancers.

The purpose of our study was to evaluate the prognostic significance of these tumor biomarkers as tumor suppressors relative to the information derived from established clinicopathological variables in gastric cancers.

\section{MATERIALS AND METHODS}

\section{Patients and tumor specimens}

One hundred and two patients who underwent surgery for gastric cancer from July 1992 to June 1993 at Chonnam National University Hospital, Gwangju, Korea were selected retrospectively for this study. The patients' ages ranged between 28 and 79 years (mean, 58.4). 65 were male and 37 were female. The size of tumors ranged between 0.5 and $15.0 \mathrm{~cm}$ (mean, 5.1). No patient had received chemotherapy or radiation therapy before surgery. The tumors were staged at the time of surgery by the standard criteria for TNM staging used by the American Joint Committee on Cancer $^{27}$. Patient characteristics including sex, age, histologic grade, stage and survival data, were obtained from medical records and pathologist and physician contact when necessary. Survival was measured until follow-up at June 2002. The clinicopathological characteristics of the study populations are summarized in Table 1.

\section{Immunohistochemistry}

Immunohistochemical staining was performed by the MicroProbe staining system (Fisher Scientific, Pittsburgh, PA) based on capillary action ${ }^{281}$. Paraffin sections, of $4 \mu \mathrm{m}$ in thickness with mounted probe on slides, were immunostained with antimouse monoclonal antibodies by the avidin-biotin peroxidase complex method ${ }^{281}$. Sections were deparaffinized and heated in a microwave oven for 7 minutes to retrieve the antigens. They were immersed in $0.6 \%$ hydrogen peroxide for 5 minutes to block the endogenous peroxidase activity. The primary antibodies used were a mouse monoclonal antibody
Table 1. Clinicopathological characteristics of 102 patients with gastric cancers

\begin{tabular}{lc}
\hline \hline \multicolumn{1}{c}{ Characteristics } & Value \\
\hline Age (yrs): Mean \pm SD (range) & $58.4 \pm 10.8$ (28-79) \\
Sex (Male:Female) & $65: 37$ \\
Tumor size (cm): Mean $\pm S D$ (range) & $5.1 \pm 2.9(0.5-15.0)$ \\
Lauren classification (Intestinal:Diffuse:Mixed) & $45: 32: 25$ \\
Histologic grade (WD:MD:PD) & $19: 26: 57$ \\
TNM stage (1:II:III:IV) & $41: 13: 28: 20$ \\
Depth of invasion (T1:T2:T3:T4) & $17: 28: 47: 10$ \\
Lymph node metastasis (Negative:Positive) & $49: 53$ \\
Distant Metastasis (Negative:Positive) & $86: 16$ \\
\hline
\end{tabular}

SD, Standard deviation; WD, Well differentiated; MD, Moderately differentiated: PD, Poorly differentiated; COX-2, Cyclooxygenase-2.

against human p21 protein (Santa Cruz Biotechnology, Santa Cruz, Calf. USA) in a 1:200 dilution and human p53 protein (Dakopatts, Glostrup, Denmark) in a 1:100. The primary antibodies, in the aforementioned concentrations were diluted in phosphate-buffered saline supplemented with $5 \%$ normal horse serum and $1 \%$ bovine serum albumin and then incubated with tissues for 120 minutes at room temperature. Anti-mouse immunoglobulin G (Sigma, St. Louis, MO) labeled with biotin was added as a secondary antibody for the detection of primary antibodies and the samples were incubated for 7 minutes at $45^{\circ} \mathrm{C}$. After multiple rinses with universal buffer, streptavidin-alkaline phosphatase detection system (Biomeda, Foster, CA) was applied for 7 minutes. As the final step, the slides were developed for 20 minutes with the enzyme substrate 3 amino-9-ethyl carbazole (AEC, Sigma, St. Louis, MO). The slides were counterstained with hematoxylin solution for 1 minute (Research Genetics, Huntsville, AL). After dehydration, the tissue was sealed with a universal mount (Research Genetics, Huntsville, AL). Normal immunoglobulin $\mathrm{G}$ was substituted for each primary antibody as negative control.

\section{Scoring of p21 and p53 expression}

According to a previous report, p21 and p53 immunoreactivity was assessed as being positive only when tumors exhibited intense nuclear staining, and reactivity was categorized into 2 groups: negative expression (less than 10\% positive tumor cells) and positive expression (at least 10\% positive tumor cells) ${ }^{29,} 30$. Assessment of immunoreactivity was evaluated by two independent observers without knowledge of the corresponding clinicopathological data. 


\section{Statistical analysis}

The $\chi^{2}$-test and Fisher's exact test, where appropriate, were used to compare the expression of p21 and p53 with various clinicopathological variables. Survival curves were calculated using the Kaplan-Meier method and analyzed by the log-rank test. The statistical software program used was Statistical Package for the Social Sciences (SPSS/PC+ 10.0, Chicago, IL). Findings of $p<0.05$ were taken to indicate statistical significance.

\section{RESULTS}

Expression of p21 and p53 in gastric cancer tissues

p21 and p53 immunoreactivities were localized in the nuclei of carcinoma cells (Figure 1). According to our criteria, positive nuclear expression of p21 and p53 was demonstrated in 63.7 $(65 / 102)$ and $33.3 \%$ (34/102) of cancer tissues, respectively (Table 1). $22(21.6 \%)$ of the cases were p21 negative and p53 negative, $46(45.1 \%)$ were p21 positive and p53 negative, 14 (13.7\%) were p21 negative and p53 positive and $20(19.6 \%)$ were p21 positive and p53 positive (Table 2). The expression of p21 did not correlate with that of p53 (Table 3).
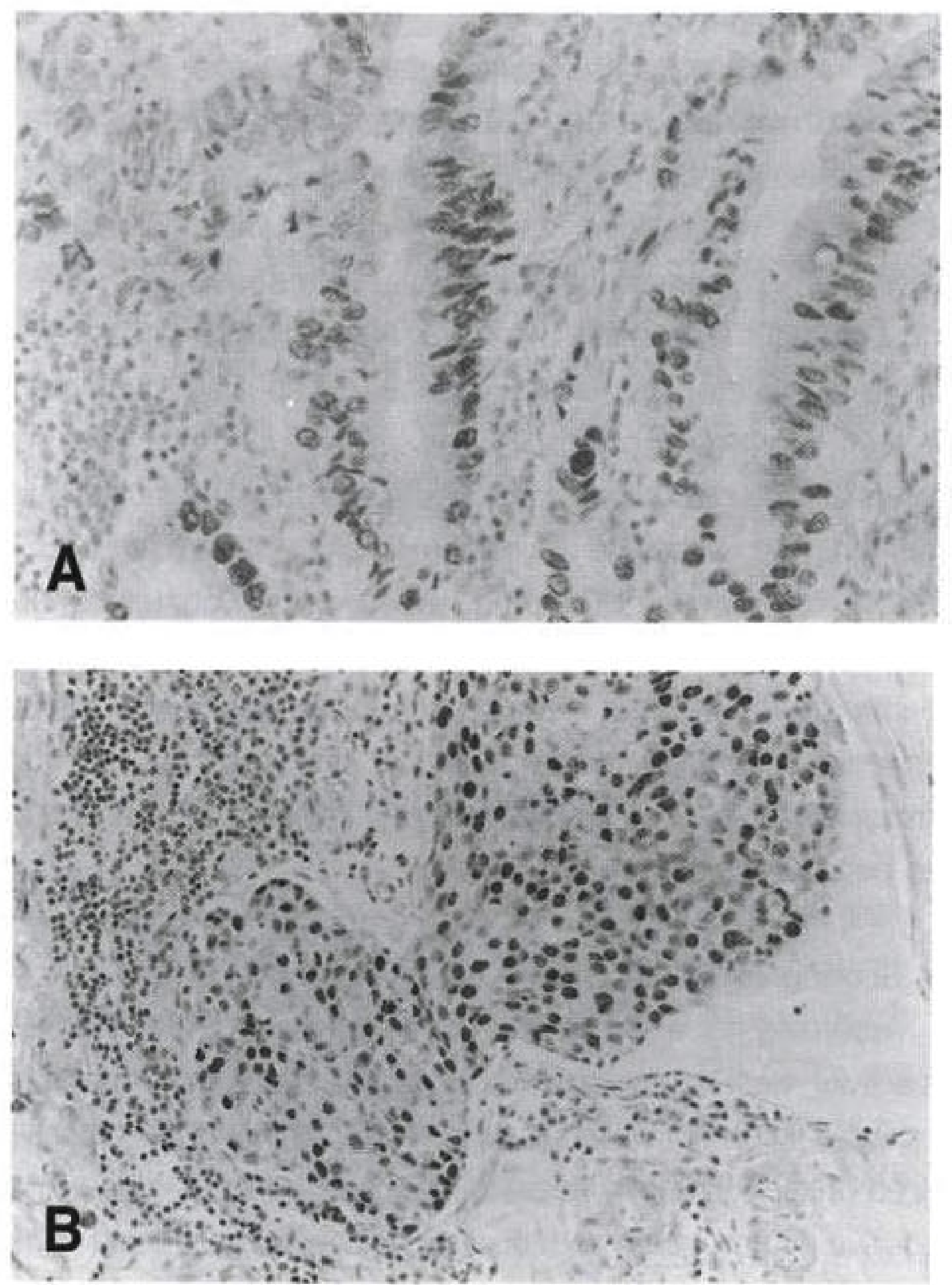

Figure 1. Typical immunohistochemical staining of p21 and p53 in gastric cancer tissue. Intense nuclear localization of p21 (A) and p53 protein $(B)$ is detected in tumor cells $(\times 200)$.
Table 2. Frequency distribution for the expression of $p 21$ and $p 53$ in 102 gastric cancers

\begin{tabular}{ll}
\hline \hline p21/p53 expression & $\mathrm{n}(\%)$ \\
\hline p21 & $37(36.3)$ \\
Negative & $65(63.7)$ \\
Positive & \\
p53 & $68(66.7)$ \\
Negative & $34(33.3)$ \\
Positive & \\
p21/p53 & \\
Negative/Negative & $22(21.6)$ \\
Positive/Negative & $46(45.1)$ \\
Negative/Positive & $14(13.7)$ \\
Positive/Positive & $20(19.6)$ \\
\hline
\end{tabular}

Table 3. Correlation between p21 and p53 expression in gastric cancers

\begin{tabular}{lccc}
\hline & \multicolumn{2}{c}{ p21 expression } & \\
\cline { 2 - 3 } & Negative $(n=37)$ & Positive $(n=65)$ & \\
\hline Negative $(n=68)$ & 23 & 45 & \\
Positive $(n=34)$ & 14 & 20 & 0.467 \\
\hline
\end{tabular}

Relationship between p21 and p53 expression and clinicopathological variables

The correlation between p21 or p53 expression and clinicopathological variables is summarized in Table 4. Negative expression of p21 correlated with the advanced stage and lymph node metastasis ( $p=0.028$ and 0.017 , respectively) and positive expression of p53 correlated with the depth of tumor invasion $(p=0.029)$.

Relationship between p21 and p53 expression and survival

Negative expression of p21 correlated with poor survival $(p=0.037)$ (Figure 2). In contrast, there was no apparent association between survival and expression of p53 ( $p=0.080)$ (Figure 3). Combined analysis of p21 and p53 status showed that p21 negative and p53 positive tumor had poorer survival than other group tumors $(p=0.026)$ (Figure 4).

\section{DISCUSSION}

Tumor formation and growth are characterized by uncontrolled cellular proliferation. This is usually the result of multiple genetic and epigenetic insults to the cell, particularly involving proto-oncogenes and tumor suppressor genes ${ }^{311}$. 
Table 4. Correlation between p21 or p53 expression and clinicopathological variables in gastric cancers

\begin{tabular}{|c|c|c|c|c|c|c|c|}
\hline \multirow{2}{*}{$\begin{array}{l}\text { Clinicopathological } \\
\text { variables }\end{array}$} & \multirow{2}{*}{$\begin{array}{c}\text { Total } \\
(n=102)\end{array}$} & \multicolumn{3}{|c|}{ p21 } & \multicolumn{3}{|c|}{ p53 } \\
\hline & & - & + & $p$-value & - & + & $p$-value \\
\hline \multicolumn{8}{|c|}{ Depth of tumor invasion $(\mathrm{T})$} \\
\hline $\mathrm{T} 1$ & 17 & 5 & 12 & 0.057 & 15 & 2 & 0.029 \\
\hline T2 & 28 & 5 & 23 & & 13 & 15 & \\
\hline T3 & 47 & 22 & 25 & & 33 & 14 & \\
\hline T4 & 10 & 5 & 5 & & 7 & 3 & \\
\hline \multicolumn{8}{|c|}{ Lymph node metastasis (N) } \\
\hline Absence & 49 & 12 & 37 & 0.017 & 34 & 15 & 0.575 \\
\hline Presence & 53 & 25 & 28 & & 34 & 19 & \\
\hline \multicolumn{8}{|c|}{ Distant metastasis (M) } \\
\hline Absence & 86 & 28 & 58 & 0.070 & 56 & 30 & 0.441 \\
\hline Presence & 16 & 9 & 7 & & 12 & 4 & \\
\hline \multicolumn{8}{|l|}{ TNM stage } \\
\hline 1 & 41 & 8 & 33 & 0.028 & 28 & 13 & 0.603 \\
\hline$\|$ & 13 & 6 & 7 & & 9 & 4 & \\
\hline III & 28 & 12 & 16 & & 16 & 12 & \\
\hline IV & 20 & 11 & 9 & & 15 & 5 & \\
\hline
\end{tabular}

+ , positive expression; -, negative expression.

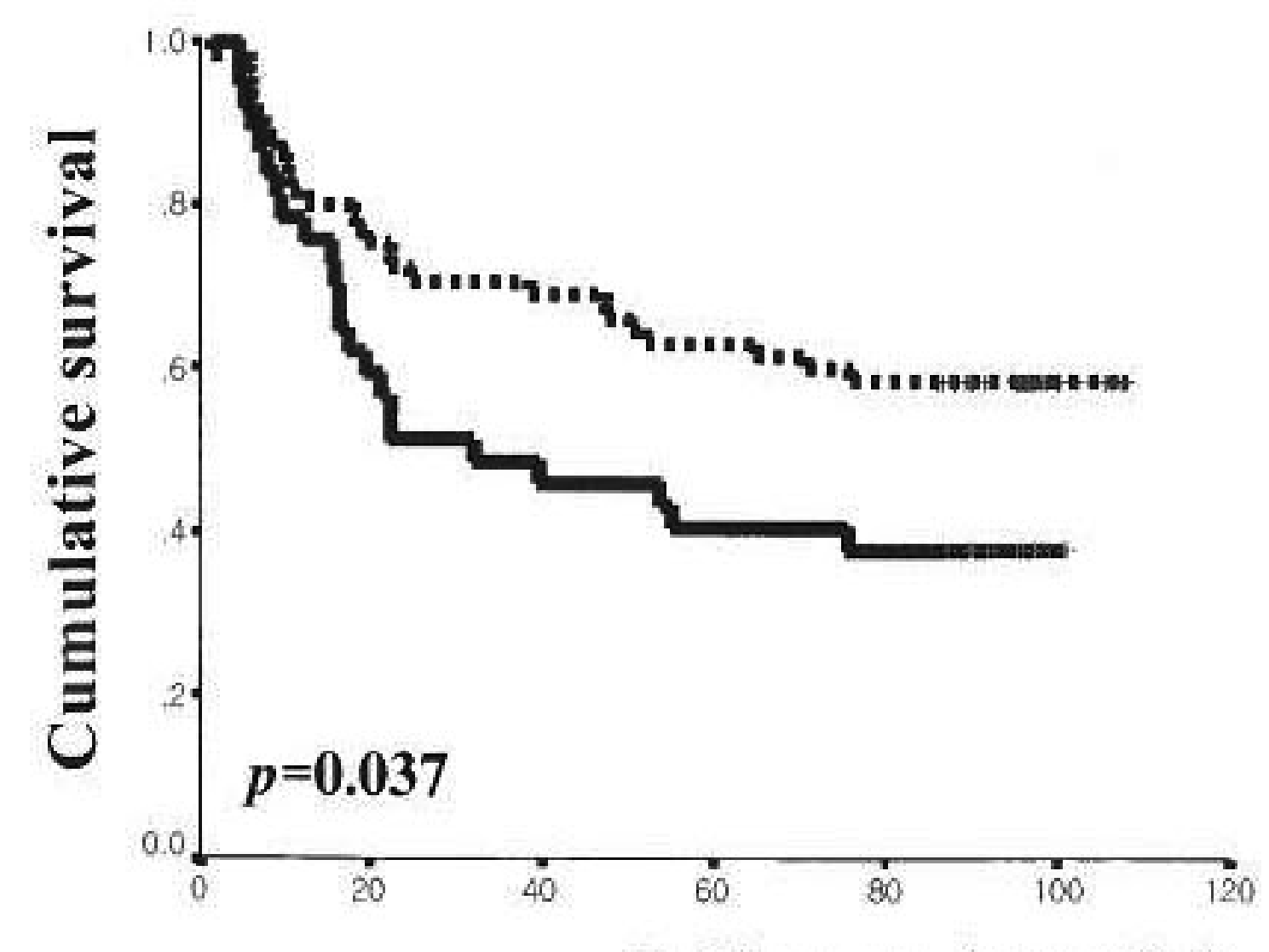

Follow up (months)

Figure 2. Kaplan-Meier survival curve correlating disease specific survival with positive (solid line) or negative (dotted line) expression of $\mathrm{p} 21$.

The dysfunction of p53, a tumor suppressor gene, has been regarded as the most significant event in the pathogenesis of cancer. Mutation of p53 lost its suppressor function and also gained new function which altered the phenotypic features of tumor cells. Mutation of p53 has been investigated in a wide variety of human cancers with a view to correlating possible loss of its suppressor function with tumor development, progression and prognosis ${ }^{21-24 i}$.

In our study, positive expression of p53 correlated with the depth of tumor invasion. However, there was no apparent association between survival and expression of p53. It is

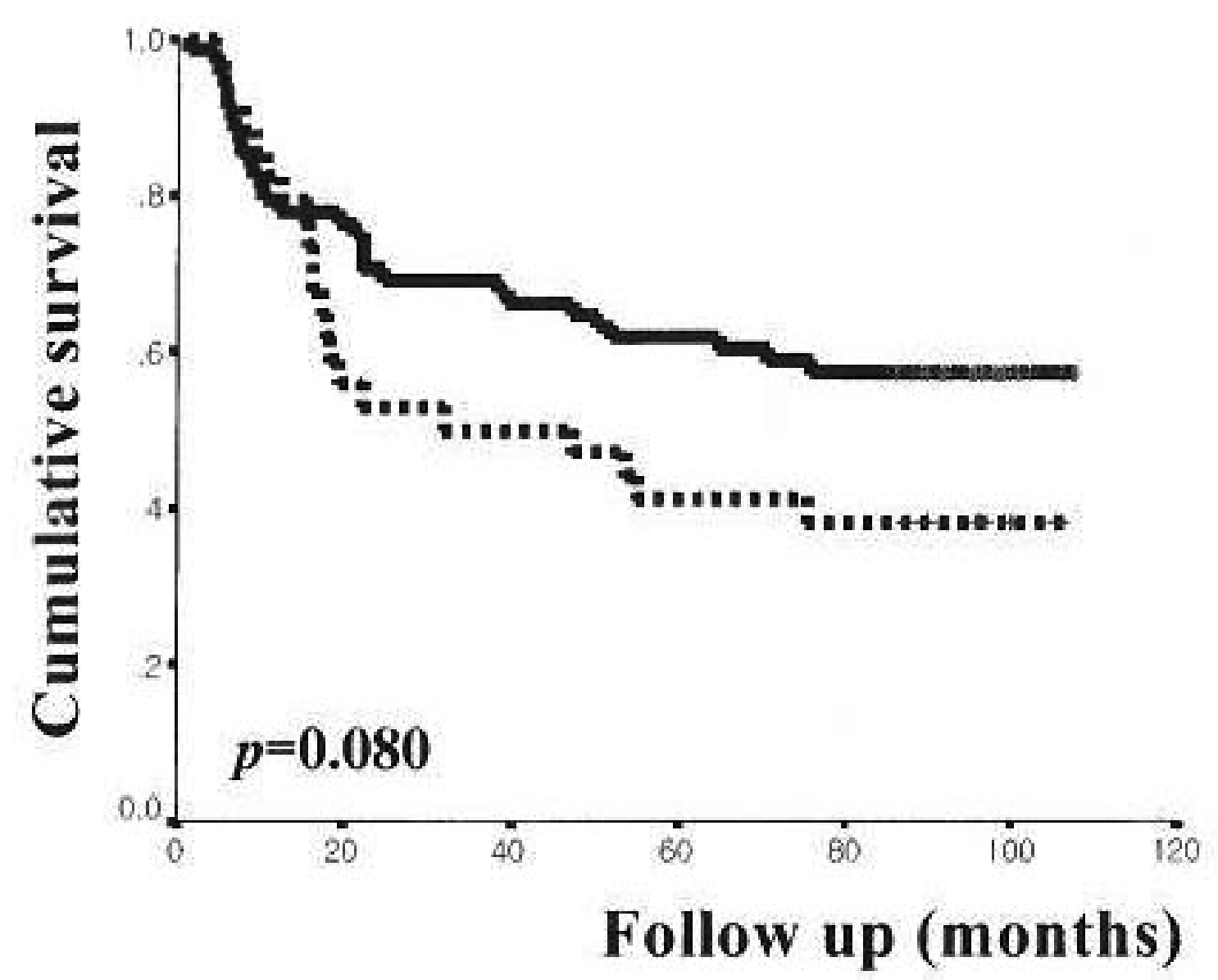

Figure 3. Kaplan-Meier survival curve correlating disease specific survival with positive (solid line) or negative (dotted line) expression of $\mathrm{p} 53$.

interesting to note that conflicting data exist regarding the predictive power of p53 status with regard to survival. These contradictory findings might be due to the methods used to establish p53 status, patient population size and the heterogeneity in the surgical treatment provided to these patients. Also, previous reports have shown discordance rates when compared with techniques that determine gene status ${ }^{321}$. Thus, the expression of p53 as detected by immunohistochemistry is not an accurate measurement of p53 function.

In recent years, alterations of the genes encoding such cell cycle regulators, as well as oncogenes and tumor suppressor 


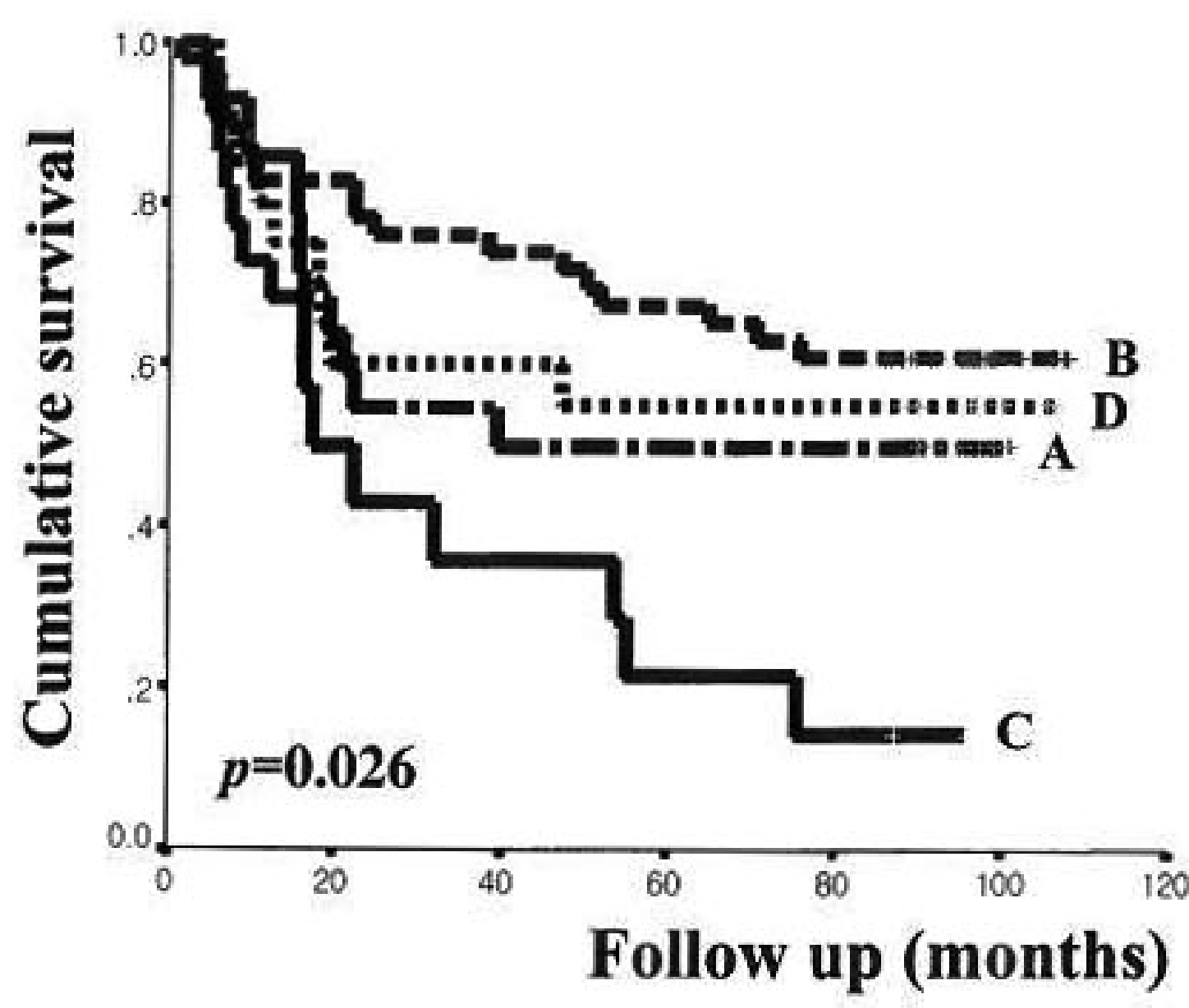

Figure 4. Kaplan-Meier survival curve for four groups of patients classified according to the status of p21 and p53 expression (A, p21 negative/p53 negative; $B$, p21 positive/p53 negative; $C$, p21 negative/p53 positive; D, p21 positive/p53 positive).

genes, have been reported to contribute to carcinogenesis ${ }^{331}$. Deregulation of cyclin, CDKs and their inhibitors could have an important role in many types of human cancers ${ }^{1-31}$. Several CDK inhibitors have been identified and potentially act as tumor suppressors. Among the many reported CDK inhibitors, it has been reported that the expression of CDK inhibitor p21 is associated with tumor suppression ${ }^{13,14,19)}$. Our study showed that negative expression of p21 correlated with the advanced stage, lymph node metastasis and poor survival. These results suggest that p21 expression may be a useful marker of prognosis. However, other studies reported that there is no significant correlation between p21 expression and the various clinicopathological parameters, including survival ${ }^{34,35}$.

p53-induced cell growth arrest is due to the potential of p53 to regulate one or more cell cycle check point-related genes, which include MDM2, Gadd45 and $\left.\mathrm{p} 21^{4}, 7,25,26\right)$. Of these targets of p53, the p21 gene is the primary mediator of p53induced cell cycle arrest. However, in our study, there was no correlation between p53 and p21 expression. Gomyo et al. and Noda et al. reported that no significant correlation is noted between p21 and p53 expression ${ }^{13,29 !}$. Also, Michieli et al. reported that serum or individual growth factors, such as platelet-derived growth factor, fibroblast growth factor and epidermal growth factor are able to induce p21 in quiescent p53-deficient cells, as well as in normal cells ${ }^{36)}$. Therefore, our results and other reports suggest that induction of p21 expression can occur via p53 independent pathways in a considerable proportion of carcinomas. Further studies are warranted to clarify the impact of $p 53$ on the function of p21 as a tumor suppressor.

Previous reports showed that the combined analysis of p21 and p53 expression yielded more accurate prognostic information $^{30,37)}$. In our study, combined analysis of p21 and p53 status also showed that p21 negative and p53 positive tumors had poorer survival than other group tumors. Our result is similar with previous reports. These results suggest that tumor progression and prognosis are not dependent on single tumor suppressor gene alteration and are regulated by multiple genetic and epigenetic insults to the cell, particularly involving tumor suppressor genes.

In conclusion, the status of p21 and p53 expression may help in predicting the aggressive behavior of gastric cancer. However, further studies are warranted to clarify the impact of p53 on the function of p21 as a tumor suppressor.

\section{REFERENCES}

1) Morgan DO. Principles of CDK regulation. Nature 374:131-134, 1995

2) Grana $X$, Reddy EP. Cell cycle control in mammalian cells: role of cyclins, cyclin-dependent kinases (CDKs), growth suppressor genes and cyclin-dependent kinase inhibitors (CKIs). Oncogene 11:211219. 1995

3) Serrano M, Hannon GJ, Beach D. A new regulatory motif in cell-cycle control causing specific inhibition of cyclin D/CDK4. Nature 366:704-707, 1993

4) Harper JW, Adami GR, Wei N, Keyomarsi K, Elledge SJ. The p21 Cok-interacting protein Clp1 is a potent inhibitor of G1 cyclindependent kinases. Cell 75:805-816, 1993

5) Xiong $\mathrm{Y}$, Hannon GJ, Zhang H, Casso D, Kobayashi R, Beach D. p21 is a universal inhibitor of cyclin kinases. Nature 366:701-704. 1993

6) Polyak $\mathrm{K}$, Lee $\mathrm{MH}$, Erdjument-Bromage $\mathrm{H}$, Koff $\mathrm{A}$, Roberts JM, Tempst P, Massague J. Cloning of p27Kipt, a cyclin-dependent kinase inhibitor and a potential mediator of extracellular antimitogenic signals. Cell 8:59-66, 1994

7) el-Deiry WS, Tokino T, Velculescu VE, Levy DB, Parsons R, Trent JM, Lin D, Mercer WE, Kinzler KW, Vogelstein B. WAFt, a potential mediator of p53 tumor suppression. Cell 75:817-825, 1993

8) Lee MH, Reynisdottir I, Massague J. Cloning of p57KIP2, a cyclin-dependent kinase inhibitor with unique domain structure and tissue distribution. Genes Dev 9:639-649, 1995

9) Hannon GJ, Beach D. p15INK4B is a potential effector of TGF-beta-induced cell cycle arrest. Nature 371:257-261, 1994

10) Hussussian CJ, Struewing JP, Goldstein AM, Higgins PA, Ally DS, Sheahan MD, Clark WH Jr, Tucker MA, Dracopoli NC. Germline p16 mutations in familial melanoma. Nat Genet 8:15-21, 1994

11) Lee YY, Kang SH, Seo JY, Jung CW, Lee KU, Choe KJ, Kim BK, Kim NK, Koeffler HP, Bang YJ. Alterations of p16INK4A and p15INK4B genes in gastric carcinomas. Cancer 80:1889-1896, 1997

12) Hirai $H$, Roussel MF, Kato JY, Ashmun RA, Sherr CJ. Novel INK4 proteins, $p 19$ and 018 are specific inhibitors of the cyclin Ddependent kinases CDK4 and CDK6. Mol Cell Biol 15:2672-2681, 1995

13) Gomyo Y, Ikeda M, Osaki M, Tatebe S, Tsujitani S, Ikeguchi M, Kaibara N, lto H. Expression of $p 21$ (waft/cipt/sdit), but not $p 53$ protein, is a factor in the survival of patients with advanced gastric carcinoma. Cancer 79:2067-2072, 1997 
141 Ogawa M, Maeda K, Onoda N, Chung YS, Sowa M. Lass of D2IWAFI/CIP1 expression correlales with disease progression in gasinc carcinoma. Br J Cancer 75:1617-1620, 1997

15 Catzavelos C. Bhattacharya N, Ung YC, Wilson JA, Roncari L, Sandhu C. Shaw P, Yeger H, Morava-Protzner I, Kapusta L, Franssen E, Pritchard KI, Slingerland JM. Decreased levels of the cell-cycle inhibitor p27Kipl protein: prognoslic implications in onmary breast cancer. Nat Med 3:227-230. 1997

16. Loda M. Cukor B, Tam SW, Lavin P, Fiorentino M, Draetta GF, Jessup $\mathrm{M}$, Pagano $\mathrm{M}$. Increased proteasome-dependent degradation of the cyclin-dependent kinase inhibitor p27 in agoressive colorectal carcinomas. Nat Med 3:231-234, 1997

17. Esposito V, Baldi A, De Luca A, Groger AM, Loda M, Giordano GG. Caputi M, Baldi F, Pagano M, Giordano A. Prognostic role of the cyclin-dependent kinase inhibitor p27 in non-small cell lung cancer. Cancer Res 57:3381-3385. 1997

18. Yasui W, Kudo Y, Semba S, Yokozaki H, Tahara E. Reduced expression of cyclin-dependent kinase inhibitor p27kipt is associated with advanced stage and invasiveness of gastric carchomas. Jpn J Cancer Res 88:625-629, 1997

19. Jang SJ, Ahn MJ, Paik SS, Kong G, Keum JS, Park YW, Lee JD. Expression of cyclin-dependent kinase inhibitor p2IWAFl alone and in combunation with $027 K I P 1$ shows prognostic value in gastric carcinoma. J Korean Med Sci 13:369-376. 1998

20. Tsihlias J. Kapusta LR, DeBoer G, Morava-Protzner I, Zbieranowski 1. Bhattacharya N, Catzavelos GC, Klotz LH, Slingerland JM. Loss of cyclin-dependent kinase inhibitor p27Kipl is a novel prognostic factor in localized human prostate adeno- carcinoma. Cancer Res $38542-548.1998$

21. Hollsiein M. Rice K. Greenblatt MS, Soussi T, Fuchs R, Sorlie T, Hovig E. Smith-Sorensen B, Montesano R, Harris CC. Database of 053 gene somatic mutations in human tumors and cell lines. Nenverc Acids Res 22:355t-3555.1994

22. Levine AJ. Perry ME, Cahng A, Silver A, Kittmer D, Wu M, Welsh D. The 1993 Waller Hubert lecture: The role of the 053 tumorsiporessor gene in lumorigenesis. $\mathrm{Br} J$ Cancer 69:409-416. 1994 $23 . \mathrm{km} \mathrm{JH}$. Uhm HD, Gong SJ, Shin DH, Choi JH, Lee HR, Noh SH, Kim? BS. Cho JY, Rha SY, Yoo NC, Chung HC, Roh JK, Min JS, Lee KS. Kim BS. Retationship between p53 overexpression and tisitric cancer progression. Oncology 54:166-170, 1997

Kakejl Y. Korenaga D, Tsujitani S, Baba H, Anai H, Maehara Y, Sugimachi K. Gastric cancer with p53 overexpression has high polentlat for metastasising to Iymph nodes. Br J Cancer 67:589-593, 1993
25) Maestro R, Gloghini A, Doglioni C, Piccinin S, Vukosavljevic $T$, Gasparotto D, Carbone A, Boiocchi M. Human non-Hodgkin's Iymohomas overexpress a wild-type form of 053 which is a functional transcriptional activator of the cyclin-dependent kinase inhibitor p21. Blood 89:2523-2528, 1997

26) Sheikh MS, Rochefort H, Garcia M. Overexpression of p21 WAF $1 /$ PI induces growth arrest, giant cell fomation and apoptosis in human breast carcinoma cell lines. Oncogene 11:1899-1905. 1995

27) American Joint Committee on Cancer Stomach cancer: Manual for slaging cancer. ed 5. revised. Philadelohia, Lippincolt-Raven, pp. 71-76. 1997

28) Reed JA, Manahan LJ, Park CS, Brigati DJ. Complele one-hour immunohistochemistry based on capillary action. Biotechniques 13:434-443. 1992

29) Noda $H$, Maehara $Y$, Irie $K$, Kakeji $Y$, Yonemura $T$, Sugimachi $K$. Growth pattern and expressions of cell cycle regutator proteins $p 53$ and p21WAFI/CIP1 in early gastric carcinoma. Cancer 92:18281835. 2001

30) Ikeguchi M, Saito $H$, Katano K, Tsujtani S, Maeta M, Kaibara N. Expression of $p 53$ and p21 are independent prognostic factors in patients with serosal invasion by gastric carcinoma. Dig Dis Sci 43 . 964-970, 1998

31) Chan AOO, Luk JM, Hui WM, Lam SK. Molecular biotogy of gastric carcinoma: From taboratory to bedside. J Gastroenterol Hepatol 14: 1150-1160, 1999

32) Dix B, Robbins P, Carrello S, Howe A, lacopetta B. Comparison of p53 gene mutation and protein overexpression in colorectal carcinomas. Br J Cancer 70:585-590, 1990

33) Sherr CJ. Cancer cell cycles. Science 274:/672-1677. 1996

34) Kaye PV, Radebold K, Isaacs S, Dent DM. Expression of $p 53$ and p2/wat1/cipt in gastric carcinoma: lack of inter-relationship or correlation with prognosis. Eur J Surg Oncol 26:39-43. 2000

35) Muller W. Noguchi T, Wirtz HC, Hommel G, Gabbert HE. Expression of cell-cycle regulatory proteins cyclin DI, cyclin E and their inhibitor p21 WAFI/CIPI in gastric cancer. J Pathol 189:186193. 1999

36) Michieli $P$, Chedid M, Lin D, Pierce JH, Mercer WE, Givol D. Induction of WAFI/CIPI by a p53-independent pathway. Cancer Res 54:3391-3395, 1994

37) Xiangming $C$, Hokita $S$, Natsugoe $S$, Tanabe G, Baba M, Takao $\mathrm{S}$, Kuroshima $\mathrm{K}_{1}$ Aikou T. p21 expression is a prognostic factor in patients with p53-negative gastric cancer. Cancer Lett 148:181-188, 2000 